\title{
Identifying and weighting elongation factors promoting science and technology parks for development of the national innovation system
}

\author{
Seyed Reza Sayahi Ardestani", Saeed Shavvalpoor and Mohammad Hassan Cheraghali
}

Department of Management and Accounting, South Tehran Branch, Islamic Azad University, Tehran, Iran

\section{H R O N I C L E}

Article history:

Received February 252014

Accepted 17 July 2014

Available online

July 202014

Keywords:

Innovation

Science and Technology parks

National innovation system

\section{Introduction}

During the past few years, there have been tremendous changes on technology development in the world and most of these changes come from innovative ideas (Higgins, 1995). Thanks to innovative I-Pad and IPhone products, Apple has become one of the world's biggest firm and customers look for new products and services (Johnson, 2010; Nicolaï \& Nicolaï, 1998; Linden et al., 2009; Hawn, 2004; Chesbrough, 2006). There are many other knowledge based firms, which rely on their creativity and innovation to develop their product and services (Phillimore, 1999). Pontiskoski and Asakawa (2009) discussed on the application of open innovation in three case examples of Apple, Nintendo, and Nokia. They described how each firm overcame barriers to utilizing open innovation strategy in R\&D and commercialization projects. They identified three levels of barriers including cognitive, behavioral, and institutional, and explained the companies balanced between internal and external resources to launch products that were instrumental in firms reinventing themselves in mature markets.

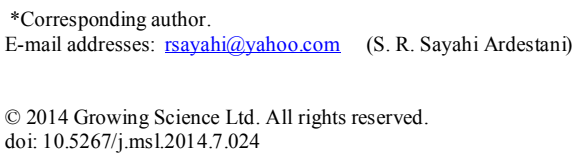


Durão et al. (2005) explained that virtual science and technology parks (V-STPs) and real-estatebased science and technology parks (RE-STPs) should not be alternative or opposed institutions but rather complementary solutions, since these two concepts may include strong synergies. They stated that the 'On Line Innovation (ONLI) project', corresponding to an 'ONLI' initiative, was a virtual European network of STPs for innovative services, developed by six organizations from various European countries under a European Union founded program.

According to Shelton (2009), product innovation alone does not generate sufficient or sustained competitive advantage and growth. Increasingly, industry leaders-such as HP, Apple, Rolls-Royce, TomTom, and GE-are complementing their product offerings with service innovations to create solutions, which build bigger customer value, improve brand preference, and create bigger crossselling opportunities. We should keep in our mind that there is a need to fuse technology and business model innovation by organizing and leveraging the appropriate resources.

Hinterhuber and Liozu (2014) presented a canvas laying out more than 20 possible methods for innovation in pricing, offering to any organization, regardless of size, industry, or nationality, a few key ideas on how to increase both profits and customer satisfaction.

\section{The proposed study}

This paper presents an empirical investigation to identify and weight elongation factors promoting science and technology parks for development of the national innovation system. The study designs a questionnaire in Likert scale and determines the relative importance of six groups of items including policy, financial resources of innovation, knowledge acquisition for innovation, upgrading innovation technology, knowledge distribution, human resources development and good and service production. The study first distributes the questionnaire among some experts to validate the overall questionnaire. Table 1 demonstrates Cronbach alphas for six items.

\section{Table 1}

The summary of Cronbach alphas calculated for six items

\begin{tabular}{lc}
\hline Item & Cronbach alpha \\
\hline Policy & 0.82 \\
Financial resources of innovation & 0.86 \\
Knowledge acquisition for innovation & 0.81 \\
Upgrading innovation technology & 0.76 \\
Knowledge distribution & 0.87 \\
Human resources development & 0.84 \\
Good and service production & 0.89 \\
\hline Total & 0.89 \\
\hline
\end{tabular}

As we can observe from the results of Table 1, all components of the survey maintain high level of values and this confirms the overall questionnaire.

\section{The results}

In this section, we present details of our findings on testing various factors.

\subsection{Policy}

The first item of the survey is associated with policy and Table 2 demonstrates the results of survey. As we can observe from the results of Table 2, all components associated with policy are statistically significant and we can conclude that they are effective on development of national innovation system. 
Table 2

The summary of the effects of policy related issues on development of national innovation system

\begin{tabular}{lccccc}
\hline Item & Mean & Mean-diff & Sig. & df & t-value \\
\hline Priority and the foundation of future activities & 4.21 & 1.71 & 0.000 & 99 & 22.61 \\
Professional management team & 4.2 & 1.77 & 0.000 & 99 & 21.72 \\
Future and national long-term plans & 4.2 & 1.70 & 0.000 & 99 & 22.60 \\
Promotion and development of strategic technologies at a competitive & 4.17 & 1.67 & 0.000 & 99 & 21.79 \\
level & 4.05 & 1.55 & 0.000 & 99 & 19.16 \\
\hline Effective management development center & & & &
\end{tabular}

\subsection{Financial resources of innovation}

The second factor is associated with financial resources of innovation with eight items described in Table 3 as follows,

Table 3

The summary of the effects of financial related issues on development of national innovation system

\begin{tabular}{|c|c|c|c|c|c|}
\hline Item & Mean & Mean-diff & Sig. & df & t-value \\
\hline Access to financial resources & 4.2 & 1.70 & 0.000 & 99 & 21.14 \\
\hline Society acceptance & 4.18 & 1.68 & 0.000 & 99 & 21.80 \\
\hline Financial support on behalf of industry & 4.15 & 1.65 & 0.000 & 99 & 18.98 \\
\hline Financial support on project with high priorities & 4.15 & 1.65 & 0.000 & 99 & 21.06 \\
\hline Capability of attracting financial support from international and NGOs & 4.06 & 1.56 & 0.000 & 99 & 17.61 \\
\hline $\begin{array}{l}\text { Capability of attracting financial support from provincial and federal } \\
\text { governments }\end{array}$ & 4.05 & 1.55 & 0.000 & 99 & 18.87 \\
\hline $\begin{array}{l}\text { Financial support of non-financial organization involved with basic } \\
\text { sciences }\end{array}$ & 4.03 & 1.53 & 0.000 & 99 & 18.07 \\
\hline Tax relief promotion plans & 4.01 & 1.51 & 0.000 & 99 & 16.75 \\
\hline
\end{tabular}

According to the results of Table 3, all financial related components influence positively on development of national innovation system.

\subsection{Knowledge acquisition for innovation}

Knowledge acquisition for innovation is the third factors influencing on development of national innovation system and Table 4 demonstrates the summary of our survey.

Table 4

The summary of the effects of knowledge acquisition factors on development of national innovation system

\begin{tabular}{|c|c|c|c|c|c|}
\hline Item & Mean & Mean-diff & Sig. & $\mathrm{df}$ & t-value \\
\hline Access to financial resources & 4.28 & 1.78 & 0.000 & 99 & 22.83 \\
\hline Society acceptance & 4.15 & 1.65 & 0.000 & 99 & 18.98 \\
\hline Financial support on behalf of industry & 4.14 & 1.64 & 0.000 & 99 & 17.19 \\
\hline Financial support on project with high priorities & 4.12 & 1.62 & 0.000 & 99 & 20.37 \\
\hline Capability of attracting financial support from international and NGOs & 4.05 & 1.55 & 0.000 & 99 & 18.08 \\
\hline $\begin{array}{l}\text { Capability of attracting financial support from provincial and federal } \\
\text { governments }\end{array}$ & 4.04 & 1.54 & 0.000 & 99 & 16.34 \\
\hline
\end{tabular}

Based on the survey results shown on Table 4, we can conclude that all six factors influence positively on development of national innovation system.

\subsection{Upgrading innovation technology}

Upgrading innovation technology is another important factor with four sub-component, summarized in Table 5. 
Table 5

The summary of the effects of factors associated with upgrading innovation technology on development of national innovation system

\begin{tabular}{|c|c|c|c|c|c|}
\hline Item & Mean & Mean-diff & Sig. & $\mathrm{df}$ & t-value \\
\hline Rate of Spin-off firms extracted from science and technology parks & 4.19 & 1.69 & 0.000 & 99 & 17.59 \\
\hline Support for newly established innovative firms & 4.04 & 1.54 & 0.000 & 99 & 18.33 \\
\hline Availability of expert human resources & 4.02 & 1.52 & 0.000 & 99 & 17.35 \\
\hline Improvement on innovation capacities for development of new ideas & 4.02 & 1.52 & 0.000 & 99 & 19.86 \\
\hline
\end{tabular}

The results of Table 5 specify that all four sub-components affect development of national innovation system.

\subsection{Knowledge distribution}

Knowledge distribution is another important factor, which is investigated in our survey. Table 6 shows the results of our survey.

\section{Table 6}

The summary of the effects of factors associated with knowledge distribution on development of national innovation system

\begin{tabular}{|c|c|c|c|c|c|}
\hline Item & Mean & Mean-diff & Sig. & $\mathrm{df}$ & t-value \\
\hline Generation and distribution of technological opportunities & 4.07 & 1.57 & 0.000 & 99 & 18.09 \\
\hline Improved and timely distribution of knowledge and technology in firms & 4.07 & 1.57 & 0.000 & 99 & 21.55 \\
\hline $\begin{array}{l}\text { Recipients of capacity building and improved social context of science } \\
\text { and Technology and innovation in community }\end{array}$ & 4.05 & 1.55 & 0.000 & 99 & 19.78 \\
\hline Combining a cluster of units as well as creating synergies & 4.03 & 1.53 & 0.000 & 99 & 16.71 \\
\hline
\end{tabular}

The results of Table 6 clearly show that all components of the survey influence on development of national innovation system.

\subsection{Human resources development}

Human resources development (HRM) with six components is another component of the survey, which influences on development of national innovation system and Table 7 summarizes the results of our survey.

\section{Table 7}

The summary of the effects of HRM related factors on development of national innovation system

\begin{tabular}{|c|c|c|c|c|c|}
\hline Item & Mean & Mean-diff & Sig. & $\mathrm{df}$ & t-value \\
\hline Availability of workforce & 4.17 & 1.67 & 0.000 & 99 & 21.79 \\
\hline Training, consultation and technical support & 4.13 & 1.63 & 0.000 & 99 & 20.19 \\
\hline Existence of full time employees with, at least, bachelor degree of science & 4.12 & 1.62 & 0.000 & 99 & 20.71 \\
\hline Regular replacement of university graduates & 4.11 & 1.61 & 0.000 & 99 & 17.50 \\
\hline Commercial and Business Consulting Services & 4.09 & 1.59 & 0.000 & 99 & 18.88 \\
\hline Workforce improvement program & 4.09 & 1.59 & 0.000 & 99 & 21.10 \\
\hline
\end{tabular}

The results of Table 7 demonstrate that all six factors associated with human resources development influence on development and advances of national innovation system.

\subsection{Good and service production}

In order to measure the effects of the mentioned factors on good and service production, the proposed study of this paper uses Pearson correlation ratio. Table 8 shows details of our findings. The results of 
Table 8 indicate that there were positive and meaningful relationships between different components of the survey and development of national innovation system. The highest ratio belongs to knowledge distribution system followed by upgrading innovation technology and Knowledge acquisition for innovation.

\section{Table 8}

The summary of Pearson correlation between seven factors with development of national innovation system

\begin{tabular}{lcc}
\hline Item & Pearson ratio & Sig. \\
\hline Policy & 0.31 & 0.00 \\
Financial resources of innovation & 0.475 & 0.00 \\
Knowledge acquisition for innovation & 0.452 & 0.01 \\
Upgrading innovation technology & 0.465 & 0.023 \\
Knowledge distribution & 0.549 & 0.033 \\
Human resources development & 0.313 & 0.041 \\
Good and service production & 0.442 & 0.048 \\
\hline
\end{tabular}

\section{Discussion and conclusion}

There is no doubt that any economic development on society depends on creating new ideas. It is always important to learn more about the factors influencing the development of national innovation system. In this paper, we have presented an empirical investigation to determine important factors in this field in Iran. The study has determined that all seven groups of items including policy, financial resources of innovation, knowledge acquisition for innovation, upgrading innovation technology, knowledge distribution, human resources development and good and service production could contribute on innovation technology development. The results of our survey are consistent with findings earlier reported by Sun et al. (2007), Woodruff (1997) and Kandampully and Duddy (1999).

\section{Acknowledgement}

The authors would like to thank the anonymous referees for constructive comments on earlier version of this paper.

\section{References}

Chesbrough, H. W. (2006). The era of open innovation. Managing innovation and change, 127(3), $34-41$.

Durão, D., Sarmento, M., Varela, V., \& Maltez, L. (2005). Virtual and real-estate science and technology parks: a case study of Taguspark. Technovation, 25(3), 237-244.

Hawn, C. (2004). If he's so smart... Steve Jobs, Apple, and the limits of innovation. Fast Company, $78(1)$.

Higgins, J. M. (1995). Innovation: the core competence. Strategy \& Leadership,23(6), 32-36.

Hinterhuber, A., \& Liozu, S. M. (2014). Is innovation in pricing your next source of competitive advantage?. Business Horizons, 57(3), 413-423.

Johnson, B. (2010). Apple iPad will choke innovation, say open internet advocates. The Guardian.

Kandampully, J., \& Duddy, R. (1999). Competitive advantage through anticipation, innovation and relationships. Management Decision, 37(1), 51-56.

Linden, G., Kraemer, K. L., \& Dedrick, J. (2009). Who captures value in a global innovation network?: the case of Apple's iPod. Communications of the ACM,52(3), 140-144.

Nicolaï, J., \& Nicolaï, N. J. (1998). Apple market and product innovation in Europe. Compact Fruit tree, Belgium, 31(3), 66-68.

Phillimore, J. (1999). Beyond the linear view of innovation in science park evaluation An analysis of Western Australian Technology Park. Technovation,19(11), 673-680. 
Pontiskoski, E., \& Asakawa, K. (2009). Overcoming barriers to open innovation at Apple, Nintendo and Nokia. World Academy of Science, Engineering and Technology, 53, 372-377.

Shelton, R. (2009). Integrating product and service innovation. Research-Technology Management, 52(3), 38-44.

Sun, H., Ni, W., \& Leung, J. (2007). Critical Success Factors for Technological Incubation: Case Study of Hong Kong Science and Technology Parks. International Journal of Management, 24(2).

Woodruff, R. B. (1997). Customer value: the next source for competitive advantage. Journal of the Academy of Marketing Science, 25(2), 139-153. 